\title{
Hubungan Faktor Individual, Sosial dan Pekerjaan dengan Kepuasan Kerja Perawat di Instalasi Gawat Darurat RSUP Dr. M. Djamil Padang Tahun 2013
}

\author{
Rusmanwadi $^{a}$, Yulastri Arif ${ }^{b}$, Ema Julita $^{a}$ \\ ${ }^{a}$ RSUP Dr. M. Djamil Padang \\ ${ }^{b}$ Fakultas Keperawatan Universitas Andalas
}

\begin{abstract}
Employee dissatisfaction in the work will have an unfavorable situation for the organization and individual. Indicator of job dissatisfaction seen in ER DR M Djamil Hospital is the high rate of absenteeism, increased morbidity, turn over and the other of work discipline problems. This study purposes to determine the relationship of individual factors (interests and attitudes), social factors (interactions with fellow nurse and supervisor) and occupational factors (work conditions and supervision) with job satisfaction of nurses in emergency rooms DR M Djamil Hospital Padang. Research design using descriptive analytic with cross sectional study in which the sample is the entire population and nurses in emergency rooms DR M Djamil Hospital Padang, amounting to 45 people. To determining of the relationship between variables using chi square test and logistic regression. The test results are statistically significant relationship between interests and job satisfaction $(p=0.004)$, attitudes and job satisfaction $(p=0.003)$, the interaction of employees with employer and job satisfaction $(p=0.000)$, supervision and job satisfaction $(p=0.000)$, there is no significant relationship between the interaction of fellow employees with job satisfaction $(p=0.334)$, working conditions and job satisfaction $(p=0.727)$, while the results of logistic regression showed that supervision is the most dominant variables associated with job satisfaction $(p=0.002)$ Expected results of the study can be used by managerial of nursing to further improve the job satisfaction of nurses in order to improve the quality of health services, especially nursing care in the ER.
\end{abstract}

Key words: job satisfaction, interest, attitude, interaction, work conditions, supervision.

\begin{abstract}
Abstrak: Ketidakpuasan karyawan dalam bekerja akan mengakibatkan suatu situasi yang tidak menguntungkan bagi organisasi maupun individual. Indikator ketidakpuasan kerja yang terlihat di IGD RS DR M Djamil adalah tingginya angka ketidakhadiran, meningkatnya angka kesakitan dan turn over serta masalah kedisiplinan kerja lainnya. Penelitian ini bertujuan untuk mengetahui hubungan faktor individual (minat dan sikap), faktor sosial (interaksi sesama perawat dan dengan atasan) dan faktor pekerjaan (kondidi kerja dan pengawasan) dengan kepuasan kerja perawat di ruangan IGD RS DR M Djamil Padang. Desain penelitian menggunakan desain deskriptif analitik dengan pendekatan cross sectional study dimana populasi dan sampelnya adalah seluruh perawat pelaksana di ruangan IGD RS DR M Djamil Padang yang berjumlah 45 orang. Untuk mengetahui hubungan antar variabel dilakukan uji chi square. Untuk mengetahui variabel mana yang paling dominan dilakukan dengan uji regresi logistik. Hasil uji statistik terdapat hubungan bermakna antara minat dengan kepuasan kerja $(\mathrm{p}=0,004)$, sikap dengan kepuasan kerja $(\mathrm{p}=0,003)$, interaksi karyawan dengan atasan dengan kepuasan kerja $(\mathrm{p}=0,000)$, pengawasan dengan kepuasan kerja $(\mathrm{p}=0,000)$, tidak terdapat hubungan bermakna antara interaksi sesama karyawan dengan kepuasan kerja $(\mathrm{p}=0,334)$, kondisi kerja dengan kepuasan kerja $(\mathrm{p}=0,727)$, sedangkan hasil uji regresi logistik didapatkan bahwa pengawasan adalah variabel yang paling dominan berhubungan dengan kepuasan kerja $(\mathrm{p}=0,002)$. Diharapkan hasil penelitian dapat digunakan oleh manajerial keperawatan untuk dapat lebih meningkatkan kepuasan kerja perawat dalam rangka meningkatkan kualitas pelayanan kesehatan khususnya pelayanan keperawatan di IGD.
\end{abstract}

Kata kunci: kepuasan kerja, minat, sikap, interaksi, kondisi kerja, pengawasan. 


\section{PENDAHULUAN}

Kepuasan kerja sudah menjadi unsur yang penting dalam dunia kerja, baik itu dalam bidang industri maupun dibidang klinis seperti keperawatan. Menurut Nursalam (2011) kepuasan kerja dalam keperawatan merupakan perasaan yang menyokong untuk mendapatkan hasil kerja yang optimal. Ketika seorang perawat merasakan kepuasan dalam bekerja, tentunya dia akan berusaha semaksimal mungkin untuk dapat menyelesaikan pekerjaannya.

Keberhasilan organisasi dalam mencapai tujuan tidak terlepas dari peran pegawainya. Pegawai bukan semata obyek dalam pencapaian tujuan organisasi, tetapi juga menjadi subyek atau pelaku. Mereka dapat menjadi perencana, pelaksana dan pengendali yang selalu berperan aktif dalam mewujudkan tujuan organisasi, serta mempunyai pikiran, perasaan dan keinginan yang dapat mempengaruhi sikapnya terhadap pekerjaan. Dalam interaksi tersebut, pegawai memberikan kontribusi kepada organisasi berupa kemampuan, keahlian dan keterampilan yang dimiliki, sedangkan organisasi diharapkan memberi imbalan dan penghargaan kepada pegawai secara adil sehingga dapat memberikan kepuasan (Salmon, 2006 dalam Wahyuni, 2010).

Kepuasan kerja adalah sikap umum terhadap pekerjaan seseorang yang menunjukkan perbedaan antara jumlah penghargaan yang diterima pekerja dan jumlah yang mereka yakini seharusnya mereka terima (Robins, 2003 dalam Wibowo, 2012). Masih dalam Wibowo (2012) Gibson (2000) menyatakan kepuasan kerja sebagai sikap yang dimiliki pekerja tentang pekerjaan mereka, hal tersebut merupakan hasil dari persepsi mereka tentang pekerjaan.

Menurut Arwani (2006) kepuasan kerja perawat perlu mendapat perhatian serius dari pihak manajemen rumah sakit karena perawat merupakan karyawan terbesar dan ujung tombak pelaksana pelayanan serta tenaga yang berinteraksi langsung dengan pasien dan keluarganya. Citra rumah sakit dipengaruhi oleh pelayanan yang diberikan oleh perawat. Instalasi gawat darurat sebagai unit pelayanan di rumah sakit merupakan etalasenya rumah sakit. Perawat sebagai profesi selalu menjadi sorotan bagi pasien dan keluarganya. Fenomena yang sering ditemui di IGD adalah keluhan terhadap perawat yang santai, kurang tanggap terhadap keluhan pasien, kurang ramahnya komunikasi dan lain-lain.

Hasil survei awal yang penulis lakukan di bagian IGD RS DR M Djamil Padang melalui observasi didapatkan bahwa sistem manajerial yakni pengawasan masih kurang jelas, masalah kedisiplinan kerja yakni masih adanya beberapa pegawai yang mangkir dari pekerjaan yang kadang menyebabkan interaksi sesama karyawan terjalin kurang baik, tentang absensi karyawan dimana didapatkan data ketidakhadiran selama tiga bulan, yaitu pada bulan Oktober, November dan Desember 2012, dari 45 orang jumlah perawat yang aktif, didapatkan rata-rata ketidakhadiran sebesar 3,48\%, dan ini cenderung naik bila dibandingkan dengan periode tiga bulan sebelumnya sebesar $3,02 \%$. Ketidakhadiran ini juga disebabkan oleh meningkatnya angka kesakitan perawat dari $26,6 \%$ pada periode yang sama menjadi $37,7 \%$ pada periode berikutnya. Penulis juga memperoleh data angka kecelakaan kerja, selama periode JuliDesember 2012 ditemukan 6 kasus kecelakaan kerja dimana kasus terbanyak yaitu tertusuk jarum sebanyak $50 \%$. Sedangkan angka turn over atau perputaran pegawai selama tahun 2012 adalah sebanyak 6 orang atau sekitar 17,6\%.

Menurut Salafi (2008) dalam penelitiannya menyebutkan bahwa ketidakpuasan kerja dapat menjadi pemicu terjadinya kecelakaan kerja sebagai akibat penurunan kesiagaan seseorang terhadap bahaya. Selain itu, ketidakpuasan dalam kerja juga dapat menyebabkan penurunan derajat kesehatan, tingginya ketidakhadiran dan keluarnya pegawai. 
Hasil wawancara yang dilakukan dengan 10 orang perawat bagian IGD RS DR M Djamil Padang mengatakan bahwa keluhan perawat muncul berkenaan dengan besaran insentif atau jasa pelayanan yang mereka terima belum sesuai dengan beban kerja yang mereka lakukan, keluhan juga dirasakan pada faktor pengaturan jadwal dinas yang sepenuhnya menjadi wewenang kepala ruangan. Tingginya tingkat stres yang mereka rasakan karena berhubungan dengan pasien dalam kondisi gawat dan tidak terduga dengan rata-rata 105 pasien perhari dengan rentang jumlah pasien pershift dinas sebanyak 26-42 orang (bulan Januari dan Februari 2013), ditambah dengan jumlah perawat yang kurang dalam shift dinas sore dan malam yaitu 5-6 perawat juga merupakan keluhan dari karyawan. Berdasarkan data-data dan fenomena tersebut, maka penulis tertarik untuk melakukan penelitian analisa kepuasan kerja perawat Di Instalasi Gawat Darurat RS DR M Djamil Padang.

\section{METODE}

Desain penelitian ini adalah deskriptif analitik dengan pendekatan Cross Sectional Study. Populasi dalam penelitian ini adalah seluruh tenaga perawat yang berdinas di ruangan IGD RS DR M Djamil Padang yang berjumlah 45 orang. Tempat penelitian ini dilakukan di ruang IGD RS DR M Djamil Padang. Penelitian dilakukan pada tanggal 11 sampai dengan 17 April 2013. Analisis data dilakukan secara univariat, bivariat dan multivariat. Analisis univariat untuk menggambarkan distribusi frekuensi masing-masing variabel independen dan dependen. Analisis bivariat untuk melihat hubungan masing-masing variabel independen dengan variabel dependen dengan menggunakan uji $C h i$ Square, sedangkan analisis multivariat untuk melihat variabel mana yang paling dominan berhubungan dengan variabel dependen dengan menggunakan uji regresi logistik. Pengumpulan data dilakukan dengan memberikan kuesioner kepada responden.

\section{HASIL DAN PEMBAHASAN}

Pengumpulan data dilakukan selama 1 minggu dari tanggal 11-17 Maret 2013 dengan responden sebanyak 45 orang perawat yang memiliki karakteristik yaitu : sebagian besar perawat di IGD $(88,9 \%)$ berjenis kelamin perempuan, lebih dari separoh perawat di IGD $(51,1 \%)$ berada pada rentang umur 20-30 tahun, sebagian besar perawat di IGD $(84,4 \%)$ dengan tingkat pendidikan D3, dan sebagian besar perawat di IGD $(75,5 \%)$ mempunyai masa kerja antara 1-10 tahun.

Tabel 1

Hubungan Minat, Sikap, Interaksi Sesama Perawat, Interaksi Dengan Atasan, Kondisi kerja dan Pengawasan Dengan Kepuasan Kerja Perawat di Ruangan IGD RS DR M Djamil Padang Tahun 2013

\begin{tabular}{|c|c|c|c|c|c|c|c|}
\hline \multirow{3}{*}{$\begin{array}{l}\text { Faktor-faktor yang berhungan } \\
\text { dengan tingkat kepuasan kerja } \\
\text { perawat }\end{array}$} & \multicolumn{4}{|c|}{ Kepuasan kerja perawat } & \multirow{2}{*}{\multicolumn{2}{|c|}{ Jumlah }} & \multirow{3}{*}{$\begin{array}{c}\mathrm{P} \\
\text { value }\end{array}$} \\
\hline & \multicolumn{2}{|c|}{ Tinggi } & \multicolumn{2}{|c|}{ Rendah } & & & \\
\hline & $\mathrm{f}$ & $\%$ & $\mathrm{f}$ & $\%$ & f & $\%$ & \\
\hline $\begin{array}{ll}\text { Minat } & \\
\text { - } & \text { Tinggi } \\
- & \text { Rendah }\end{array}$ & $\begin{array}{c}23 \\
5\end{array}$ & $\begin{array}{l}79,3 \\
31,3\end{array}$ & $\begin{array}{c}6 \\
11\end{array}$ & $\begin{array}{l}20,7 \\
68,8\end{array}$ & $\begin{array}{l}29 \\
16\end{array}$ & $\begin{array}{l}64,4 \\
35,6\end{array}$ & 0,004 \\
\hline $\begin{array}{ll}\text { Sikap } & \\
- & \text { Positif } \\
- & \text { Negatif }\end{array}$ & $\begin{array}{c}24 \\
4\end{array}$ & $\begin{array}{l}77,4 \\
28,6\end{array}$ & $\begin{array}{c}7 \\
10\end{array}$ & $\begin{array}{l}22,6 \\
71,4\end{array}$ & $\begin{array}{l}31 \\
14\end{array}$ & $\begin{array}{l}68,9 \\
31,1\end{array}$ & 0,005 \\
\hline
\end{tabular}




\begin{tabular}{|c|c|c|c|c|c|c|c|}
\hline $\begin{array}{l}\text { Interaksi Sesama Perawat } \\
\text { - } \text { Baik } \\
\text { - } \text { Kurang Baik }\end{array}$ & $\begin{array}{l}17 \\
11\end{array}$ & $\begin{array}{l}70,8 \\
52,4\end{array}$ & $\begin{array}{c}7 \\
10\end{array}$ & $\begin{array}{l}29,2 \\
47,6\end{array}$ & $\begin{array}{l}24 \\
21\end{array}$ & $\begin{array}{l}53,3 \\
46,7\end{array}$ & 0,334 \\
\hline $\begin{array}{l}\text { Interaksi Dengan Atasan } \\
\text { - } \quad \text { Baik } \\
\text { - } \text { Kurang Baik }\end{array}$ & $\begin{array}{c}25 \\
3\end{array}$ & $\begin{array}{l}92,6 \\
16,7\end{array}$ & $\begin{array}{c}2 \\
15\end{array}$ & $\begin{array}{c}7,4 \\
83,3\end{array}$ & $\begin{array}{l}27 \\
18\end{array}$ & $\begin{array}{l}60 \\
40\end{array}$ & 0,000 \\
\hline $\begin{array}{l}\text { Kondisi Kerja } \\
\text { - } \text { Baik } \\
\text { - } \quad \text { Kurang Baik }\end{array}$ & $\begin{array}{l}17 \\
11\end{array}$ & $\begin{array}{l}58,6 \\
68,6\end{array}$ & $\begin{array}{c}12 \\
5\end{array}$ & $\begin{array}{l}41,1 \\
31,3\end{array}$ & $\begin{array}{l}29 \\
16\end{array}$ & $\begin{array}{l}64,4 \\
35,6\end{array}$ & 0,727 \\
\hline $\begin{array}{ll}\text { Pengawasan } \\
\text { - } \\
\text { - } \text { Baik } \\
\text { Kurang Baik }\end{array}$ & $\begin{array}{c}21 \\
7\end{array}$ & $\begin{array}{r}100 \\
29,2\end{array}$ & $\begin{array}{c}0 \\
17\end{array}$ & $\begin{array}{c}0 \\
70,8\end{array}$ & $\begin{array}{l}21 \\
24\end{array}$ & $\begin{array}{l}46,7 \\
53,3\end{array}$ & 0,000 \\
\hline
\end{tabular}

1. Hubungan Minat Dengan Kepuasan Kerja Perawat di Ruangan IGD RS DR M Djamil Padang

Dari hasil analisis bivariat dapat diperoleh informasi bahwa tingginya tingkat kepuasan kerja perawat cenderung terjadi lebih tinggi pada responden yang memiliki minat kerja yang tinggi yaitu sebanyak 79,3\% dibandingkan dengan responden yang memiliki minat yang rendah sebanyak $31,3 \%$. Dari hasil uji statistik continuity correction didapatkan nilai $\mathrm{p}<0,05(\mathrm{p}=0,004)$ dengan demikian ada hubungan bermakna antara minat dengan kepuasan kerja perawat.

Hasil penelitian ini sejalan dengan penelitian Prabowo (2011) yang menyatakan bahwa ada hubungan yang bermakna antara minat kerja dengan kepuasan kerja. Teori Tracey (2007) mengatakan bahwa minat sebagai salah satu dimensi ruhaniah yang akan memungkinkan seseorang untuk berupaya mencari, mengarahkan, mencurahkan perhatian dan berusaha mencapai apa yang dianggap bermakna bagi dirinya. Minat juga merupakan kecenderungan tingkah laku umum seseorang untuk tertarik kepada kelompok bidang kegiatan, aktivitas atau pekerjaan tertentu sebagai hasil dari proses belajar. Minat bukan menunjukkan kepada bagaimana seseorang akan melakukan sesuatu dan bagaimana sebaiknya melakukannya, tetapi menunjukkan kepada kemungkinan apa yang akan dilakukan oleh seseorang. Untuk itu pemantauan kesesuaian minat seseorang dengan pilihan bidang pekerjaan akan senantiasa diupayakan.

Lebih lanjut Tracey mengatakan bahwa pekerjaan akan lebih berarti bila seseorang dapat melihat dan menemukan dirinya disana. Disamping itu perasaan senang dan bahagia menolongnya untuk bekerja lebih bergairah dan giat mencapai keberhasilan. Kepuasan, kemantapan, dan hasil kerja tergantung atas kongruens antara kepribadian individu dengan lingkungan (yang sebagian terdiri dari orang-orang lain) di mana individu itu bekerja.

2. Hubungan Sikap Dengan Kepuasan Kerja Perawat di Ruangan IGD RS DR M Djamil Padang

Dari analisis bivariat dapat diperoleh informasi bahwa tingginya angka kepuasan kerja perawat cenderung tinggi terjadi pada responden yang memiliki sikap kerja yang positif sebanyak $77,4 \%$ dibanding dengan responden yang memiliki sikap kerja negatif yaitu sebanyak 28,6\%. Dari hasil uji statistik Continuity correction didapatkan nilai $\mathrm{p}<0,05(\mathrm{p}=0,005)$ dengan demikian 
terdapat hubungan bermakna antara sikap dengan kepuasan kerja perawat.

Hasil penelitian ini sejalan dengan penelitian Mursini (2004) dan Muljono (2008) yang menyatakan bahwa terdapat hubungan yang positif antara sikap dengan kepuasan kerja. Teori Azwar (2011) mengatakan bahwa sikap selalu dikaitkan dengan perilaku individu yang berada dalam situasi normal dan merupakan respon atau reaksi terhadap rangsangan lingkungan sosial pada saat itu. Dalam interaksi sosialnya, individu membentuk pola sikap tertentu terhadap berbagai objek psikologis yang dihadapinya. Menurut Robbins (2007), sikap adalah pernyataanpernyataan evaluatif baik yang diinginkan atau yang tidak diinginkan mengenai obyek, orang atau peristiwa. Tiga komponen sikap, antara lain: kognitif, afektif dan perilaku. Komponen kognitif sikap adalah segmen pendapat atau keyakinan dari sikap. Komponen afektif sikap adalah segmen emosional atau perasaan dari sikap. Komponen perilaku sikap adalah maksud untuk berperilaku dalam cara tertentu terhadap seseorang atau sesuatu.

Sikap terhadap profesi perawat adalah kumpulan elemen kognitif, afektif dan konatif didalam diri individu perawat yang berhubungan dengan manfaat tugas, pelaksanaan tugas, rasa senang terhadap pekerjaan, puas terhadap pekerjaan, kerja keras dan keinginan untuk mencapai sukses dalam profesi keperawatan. Mengacu pada uraian diatas maka peneliti berpendapat bahwa makin positif sikap perawat terhadap profesi dan pekerjaannya akan semakin tinggi pula tingkat kepuasan kerjanya dan penting bagi pihak manajerial untuk dapat lebih memperhatikan aspek sikap karyawan karena besar pengaruhnya bagi kepuasan kerja itu sendiri.

\section{Hubungan Interaksi Sesama Perawat Dengan Kepuasan Kerja}

Dari hasil analisis bivariat dapat diperoleh informasi bahwa tingginya angka kepuasan kerja perawat cenderung tinggi terjadi pada responden yang menyatakan interaksi sesama karyawan baik yaitu sebanyak 70,8\% dibandingkan dengan responden yang menyatakan interaksi sesama karyawan kurang baik yaitu sebanyak 52,4\%. Dari hasil uji statistik continuity correction didapatkan nilai $\mathrm{p} \geq$ $0,05 \quad(p=0,334)$ dengan demikian tidak terdapat hubungan bermakna antara interaksi sesama karyawan dengan kepuasan kerja perawat.

Hasil penelitian ini berbeda dengan teori yang dikemukakan oleh Robbins (2009) yang menyatakan bahwa hubungan interpersonal merupakan salah satu faktor yang turut berperan menghantar kepuasan kerja karyawan. Mempunyai rekan kerja yang ramah dan mendukung pekerjaan akan merasa mendapat lebih dari sekedar uang. Sutrisno (2012) juga menyatakan bahwa kepuasan kerja yang ada pada para pekerja timbul jika terjadi hubungan yang harmonis dengan tenaga kerja yang lain.

Hasil penelitian ini menunjukkan tidak terdapat hubungan yang bermakna antara interaksi sesama karyawan dengan kepuasan kerja perawat. Jika dilihat dari pedoman pelayanan gawat darurat, IGD adalah unit organisasi di rumah sakit yang didasarkan pada organisasi multidisiplin, multiprofesi dan terintegrasi terpadu, dari itu hubungan interpersonal yang baik di IGD mutlak diperlukan dan perawat sebagai bagian integral dari pelayanan kesehatan harus mampu bekerjasama dengan unit pelayanan lain yang terkait sebagai tim kerja. Walaupun hasil penelitian tidak menunjukkan adanya hubungan yang bermakna antara interaksi sesama karyawan dengan kepuasan kerja, hal ini dapat disebabkan oleh adanya perbedaan pandangan responden mengenai hubungan interpersonal dalam penelitian ini yaitu hanya sesama perawat, tidak menggali hubungan interpersonal dengan tim kesehatan lainnya. 


\section{Hubungan Interaksi Karyawan Dengan Atasan Dengan Kepuasan Kerja Perawat di Ruangan IGD RS DR M Djamil Padang}

Dari hasil analisis bivariat dapat diperoleh informasi bahwa tingginya angka kepuasan kerja perawat, cenderung tinggi terjadi pada responden yang menyatakan interaksi karyawan dengan atasan baik yaitu sebanyak $92,6 \%$ dibandingkan dengan responden yang menyatakan interaksi karyawan dengan atasan kurang baik sebesar 16,7\%. Dari hasil uji statistik Continuity correction didapatkan nilai $\mathrm{p}<$ $0,05(\mathrm{p}=0,000)$ dengan demikian terdapat hubungan bermakna antara interaksi dengan atasan dengan kepuasan kerja perawat.

Hasil penelitian ini sama dengan penelitian Lismarni (2002) yang menyatakan bahwa hubungan yang baik yang terbina dengan rekan kerja maupun dengan atasan akan menciptakan kondisi kerja yang menyenangkan dan mempengaruhi motivasi dan kepuasan kerja. Sejalan dengan teori yang dikemukakan oleh Sutrisno (2012) hubungan antara karyawan dengan pihak pimpinan sangat penting artinya untuk menaikkan produktivitas kerja. Kepuasan dapat ditingkatkan melalui perhatian dan hubungan yang baik dari pimpinan kepada bawahan, sehingga karyawan akan merasa bagian penting dari organisasi kerja.

Menurut analisa peneliti kepuasan kerja akan tercapai jika seseorang merasa pekerjaan yang dilakukan dihargai oleh pimpinannya. Dengan demikian produktivitas kerja naik dan semua tugas dapat dilaksanakan dengan efektif, maka ia disebut sebagai pimpinan yang berhasil.

5. Hubungan Kondisi Kerja Dengan Kepuasan Kerja Perawat di Ruangan IGD RS DR M Djamil Padang

Dari hasil analisis bivariat dapat diperoleh informasi bahwa tingginya angka kepuasan kerja perawat cenderung tinggi terjadi pada responden yang menyatakan kondisi kerja kurang baik sebanyak 68,8\% dibandingkan dengan responden yang menyatakan kondisi kerja baik sebanyak $58,6 \%$. Dari hasil uji statistik continuity correction didapatkan nilai $\mathrm{p}>0,05$ $(\mathrm{p}=0,727)$ dengan demikian tidak terdapat hubungan yang bermakna antara kondisi kerja dengan kepuasan kerja perawat.

Hasil penelitian berbeda dengan teori yang dikemukakan oleh Luthans (1992) dalam Hariandja dan Hardiwati (2002) yang mengatakan bahwa kondisi kerja merupakan salah satu faktor penunjang yang berpengaruh terhadap kepuasan kerja.

Namun dalam penelitian ini kondisi kerja tidak terlalu mempengaruhi kepuasan kerja, hal ini bisa disebabkan karena kondisi kerja memiliki bobot sumbangan yang kecil atau dengan kata lain kondisi kerja hanya memberikan sedikit kontribusi maka bisa juga tidak dianggap memiliki hubungan dengan kepuasan kerja. Disamping itu kemungkinan juga disebabkan karena kondisi ruangan IGD pada saat dilakukan penelitian memakai ruangan sementara karena ruangan IGD sedang dalam rehabilitasi fisik, sehingga beberapa aspek kondisi kerja yang dirasakan karyawan tidak mewakili keadaan sesungguhnya yang dapat mempengaruhi responden dalam mengisi kuesioner penelitian.

\section{Hubungan Pengawasan Dengan Kepuasan Kerja Perawat di Ruangan IGD RS DR M Djamil Padang}

Dari analisa bivariat dapat diperoleh informasi bahwa tingginya angka kepuasan kerja perawat terjadi pada responden yang menyatakan pengawasan baik sebanyak 100\%. Dari hasil uji statistik Continuity correction didapatkan nilai $\mathrm{p}<0,05$ $(\mathrm{p}=0,000)$ dengan demikian terdapat hubungan yang bermakna antara pengawasan dengan kepuasan kerja perawat.

Hasil penelitian juga sesuai dengan teori yang dikemukakan oleh Rivai (2004) 
bahwa pengawasan merupakan salah satu faktor yang dapat mempengaruhi kepuasan kerja sehingga produktivitas karyawan meningkat. Dengan pengawasan memungkinkan seorang pimpinan dapat menemukan berbagai kendala yang dihadapi dalam melaksanakan tugas di ruangan yang bersangkutan melalui analisis yang komprehensif bersama-sama dengan perawat pelaksana secara efektif dan efisien. Dengan pengawasan pula pimpinan dapat menghargai potensi setiap anggota atau bawahannya dan dapat menerima perbedaan serta kekurangannya sehingga dapat dimanfaatkan untuk menciptakan kepuasan kerja.

\section{Faktor Yang Paling Dominan Berhubungan Dengan Kepuasan Kerja Perawat di Ruangan IGD RS DR M Djamil Padang}

Tabel 2.

Hasil Regresi Logistik Model Akhir

\begin{tabular}{|c|c|c|c|c|}
\hline No & Variabel & $\mathrm{P}$ & OR & $\begin{array}{c}95 \% \\
\text { CI }\end{array}$ \\
\hline 1 & Pengawasan & 0,002 & 2,714 & $\begin{array}{c}0,765- \\
9,634\end{array}$ \\
\hline
\end{tabular}

Hasil analisa multivariat tahap akhir dapat dilihat pada tabel 2, menunjukkan bahwa ada satu variabel yang secara signifikan berhubungan dengan kepuasan kerja perawat dengan nilai $\mathrm{p}=0,002$ yaitu pengawasan, sehingga dalam penelitian ini variabel pengawasan adalah variabel yang paling dominan berhubungan dengan tingkat kepuasan kerja perawat di ruangan IGD RS DR M Djamil Padang tahun 2013.

Variabel pengawasan menjadi variabel yang paling dominan berhubungan dengan kepuasan kerja. Hal ini bisa saja berhubungan dengan hasil penelitian yang menunjukkan lebih dari separoh responden menyatakan pengawasan di ruangan IGD kurang baik. Hasil wawancara tidak terstruktur dengan beberapa karyawan juga menyatakan bahwa pengawasan yang dilakukan pihak manajemen IGD berjalan kurang efektif karena masih banyaknya karyawan yang kurang disiplin, seperti masih banyaknya karyawan yang keluar pada saat jam efektif kerja, istirahat sebelum waktunya dan lain-lain.

Sebagaimana dikatakan oleh Rivai dan Mulyadi (2012) pengawasan adalah suatu proses, dimana pihak manajemen melihat apakah yang telah dikerjakan karyawan sesuai dengan apa yang seharusnya terjadi. Apabila tidak demikian halnya, maka diadakan penyesuaianpenyesuaian atau penilaian yang pernah dilakukan. Lebih lanjut dikatakan bahwa terdapat faktor yang mempengaruhi pentingnya pengawasan, yaitu : belum terlaksananya pekerjaan dengan baik, tingkat absensi yang tinggi, tidak tepat waktu dalam melaksanakan tugas dan kurangnya disiplin para karyawan.

\section{KESIMPULAN DAN SARAN}

Berdasarkan hasil penelitian yang dilakukan mengenai hubungan faktor individual, sosial dan pekerjaan dengan kepuasan kerja perawat, dengan total sampel sebanyak 45 orang, maka dapat diambil kesimpulan bahwa terdapat hubungan bermakna antara faktor minat, sikap, interaksi dengan atasan dan pengawasan dengan tingkat kepuasan kerja perawat, dimana faktor yang paling dominan berhubungan yaitu faktor pengawasan.

Hasil penelitian ini menyarankan kepada pihak manajerial rumah sakit maupun ruangan IGD agar dapat lebih meningkatkan pengawasan dan interaksi dengan bawahan agar dapat tercipta suasana kerja yang kondusif. 
DAFTAR PUSTAKA

Arwani, dkk (2006), Manajemen Bangsal Keperawatan, Jakarta, EGC. Akustia, Eny (2001) Pengaruh Karakteristik Dan Faktor Kondisi Pekerjaan Dengan Kepuasan Kerja Perawat Puskesmas Di Kabupaten Pati. Diakses tanggal 28 Maret 2013 dari http://eprints.undip.ac.id/13632/

Febrianny, M. (2009), Faktor-faktor Yang Berhubungan Dengan Kepuasan Kerja Perawat Di Ruang Triase IGD RS DR M Djamil Padang, Skripsi tidak dipublikasikan.

Handoko, T.H. (2010), Manajemen Personalia dan Sumber Daya Manusia (edisi 2), Yogyakarta, BPFE.

Hariandja dan Hardiwati, (2002), Manajemen Sumber Daya Manusia, Jakarta, Grasindo.

Lismarni (2002), Faktor Internal dan Eksternal Yang Berhubungan Dengan Tingkat Kepuasan Kerja Perawat di RSUD Pariaman. Skripsi tidak dipublikasikan.

Muljono, P. ((2008), Hubungan Antara Sikap Terhadap Profesi dan Motivasi Kerja Denagn Kepuasan Kerja Penyuluh Pertanian. Diakses tanggal 30 Maret 2013 dari http://jurnalsodality.ipb.ac.id/jurnal pdf/edisi6-1.pdf
Mursini, (2004), Hubungan Sikap dan Kecerdasan Emosi Dengan Kepuasan Kerja Dosen FBS Unimed. Diakses tanggal 1 April 2013 dari http://digilib.unimed.ac.id/public/U NIMED-Article-23913-Mursini.pdf Nursalam, (2011), Managemen Keperawatan : Aplikasi Dalam Praktek Keperawatan Profesional (Edisi 3), Jakarta, Salemba Medika.

Rivai dan Mulyadi, (2012), Kepemimpinan dan Perilaku Organisasi (edisi ketiga), Jakarta, RajaGrafindo Persada.

Sutrisno, E. (2012), Manajemen Sumber Daya Manusia, (edisi pertama), Jakarta, Kencana Prenada Media Group.

Tracey, T.J.G. (2007), Moderators of the Interest CongruenceOccupational Outcome Relation. Original Paper. International Journal for Education and Vocational Guidance. Diakses tanggal 28 Maret 2013 dari http://file.upi.edu/Direktori/FIP/JU R._PSIKOLOGI_PEND_DAN_BI MBINGAN/1958070319850313_k ecocokan_minat_\%26_hasil_kerja. pdf

Wibowo, (2012), Manajemen Kinerja (edisi ketiga), Jakarta, RajaGrafindo Persada 